\title{
Comparison of surgical techniques and results for emergency or elective femoral hernia repair
}

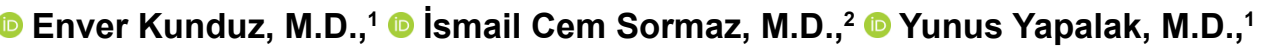 \\ (1) Hüseyin Kazım Bektaşoğlu, M.D., ${ }^{1}$ (1) Ali Fuat Kaan Gök, M.D. ${ }^{2}$
}

${ }^{1}$ Department of General Surgery, Bezmialem University Faculty of Medicine, İstanbul-Turkey

${ }^{2}$ Department of General Surgery, İstanbul University Faculty of Medicine, İstanbul-Turkey

\begin{abstract}
BACKGROUND: Inguinal hernia affects 3-8\% of the population. Femoral hernias are only a small number of groin hernias; however, femoral hernias are very important because these operations are generally emergency procedures, and bowel resections are frequently necessary. This study aims to compare surgical outcomes of patients with femoral hernias using different techniques under emergency or elective conditions.

METHODS: Between April 2013 and November 2017, 52 patients with femoral hernias were admitted to the emergency department of the General Surgery Clinics at two university hospitals in Istanbul. The medical files of all the patients who underwent surgery with a diagnosis of a femoral hernia were retrospectively evaluated. The demographic data, hernia side information, sac contents, surgical technique, length of hospital stay, recurrence according to the last outpatient clinic and complications were retrospectively analyzed.

RESULTS: The sex distribution of the cases was as follows: $88.5 \%(n=46)$ of the patients were female, and II.5\% $(n=6)$ were male. The mean age was $62.9 \pm 16.49$ years (3I-91 years). There were no significant differences between the two groups, according to the hernia side $(p=0.282)$. Thirteen of the elective cases $(52 \%)$ were operated using open techniques, and 12 cases $(48 \%)$ were operated using laparoscopic techniques.
\end{abstract}

CONCLUSION: For the comparison of surgical techniques and outcomes, prospective randomized studies should be designed to standardize broad-based surgical techniques.

Keywords: Emergency surgery; femoral hernia; laparoscopy.

\section{INTRODUCTION}

Inguinal hernia affects $3-8 \%$ of the population. ${ }^{[1,2]}$ Femoral hernias constitute $2-4 \%$ of all inguinal hernias. ${ }^{[3-5]}$ Approximately 20 million inguinal hernia surgeries per year are carried out worldwide. ${ }^{[6-8]}$ Inguinal hernia repair surgeries have been performed for many years, and many techniques have been introduced. Femoral hernias are only a small number of inguinal hernias; however, femoral hernias are very important because these operations are generally emergency procedures and bowel resections are frequently necessary. ${ }^{[7,8]}$ Emergency surgeries have been reported to increase postop- erative morbidity, but elective femoral hernia surgery does not increase morbidity, even in elderly patients..$^{[5,9]}$

The possibility of recurrence after femoral hernia repair is higher than that of inguinal hernia repair. ${ }^{[3,5]}$ McVay repair is recommended for an emergency operation with femoral hernia incarceration before the use of synthetic patches. ${ }^{[10]} \mathrm{How}$ ever, repair with sutures is more likely to cause recurrence than repair with a synthetic patch. ${ }^{[5]}$ Although complication rates have been reported to be over $50 \%$ in patients with intestinal resection, ${ }^{[10]}$ synthetic patches are recommended for resection and anastomosis. ${ }^{[5,10-13]}$ The present study aims

Cite this article as: Kunduz E, Sormaz İC, Yapalak Y, Bektaşoğlu HK, Gök AFK. Comparison of surgical techniques and results for emergency or elective femoral hernia repair. Ulus Travma Acil Cerrahi Derg 2019;25:611-615.

Address for correspondence: Enver Kunduz, M.D.

Adres bilgisi: Bezmialem Hastanesi, 4. Kat, Genel Cerrahi Sekreterliği, Vatan Caddesi, Fatih, 34093 i̇stanbul, Turkey.

Tel: +90 212 - 4531700 E-mail: drkunduz@yahoo.com

Ulus Travma Acil Cerrahi Derg 2019;25(6):6II-615 DOI: 10.14744/tites.2019.04524 Submitted: 02.01.2019 Accepted: II.02.2019 Online: I5.02.2019

Copyright 2019 Turkish Association of Trauma and Emergency Surgery 
to evaluate and compare surgical outcomes of femoral hernia cases using different techniques under emergency or elective conditions.

\section{MATERIALS AND METHODS}

Between April 2013 and November 2017, 52 patients with femoral hernias were admitted to the emergency department of the General Surgery Clinics at two university hospitals in Istanbul, Turkey. The medical files of all the patients who underwent surgery with a diagnosis of femoral hernia were retrospectively evaluated. Emergency surgery patients were defined as Group I, and elective surgery patients were defined as Group 2. The demographic data, hernia side information, sac contents, surgical technique, length of hospital stay, recurrence according to the last outpatient clinic and complications were retrospectively analyzed. Patients who had previously undergone inguinal hernia repair and/or were operated on for recurrence were excluded from this study.

Paracetamol 4x500 mg IV and narcotic analgesics (pethidine hydrochloride $4 \times 0.5 \mathrm{mg} / \mathrm{kg}$ ) were administered as pain relievers for 24 hours postoperatively in patients who were operated under elective conditions or operated under urgent conditions but without intestinal contents. Oral 4x500 mg paracetamol was administered postoperatively for at least one week. Oral fluid intake was started six hours postoperatively. All patients with tolerance were started on a regular diet.

In patients undergoing emergency surgery and bowel reduction and resection anastomosis, oral feeding was started after 24 hours and followed up for at least three days in the hospital.

Statistical analyses were performed using the Windows SSPS 16.0 (SPSS, Chicago, IL, USA) program. The results are given as means and standard deviations. Comparisons of the groups were made with chi-squared and Mann-Whitney $U$ tests. Values of $p<0.05$ were considered statistically significant.

\section{Surgical Techniques}

All of the patients were informed about the surgical technique and anaesthesia before the surgery, and their consent forms were obtained. Thromboembolism and antibiotic prophylaxis were performed before the operation. Lichtenstein repair was performed after the inguinal ligament was opened, and the femoral canal was visualized and turned into the groin. Other techniques, such as synthetic patch repair (Rutkow Plug) and laparoscopic TAPP (transabdominal preperitoneal), were performed. If the intestinal segment was strangulated in the hernia pouch and ischaemia or necrosis had occurred, segmental bowel resection and functional end-to-end anastomosis were carried out.

\section{RESULTS}

The sex distribution of the cases was as follows: $88.5 \%(n=46)$ of the patients were female, and II.5\% $(n=6)$ were male. The mean age was $62.9 \pm 16.49$ years (31-91 years). The number of patients was 27 and 25 in Groups I and 2, respectively. There were no statistically significant differences between the two groups, according to sex, and Group I patients were significantly older than Group two patients $(p=0.67$, $p=0.013)$. There were no significant differences between the two groups, according to the hernia side $(p=0.282)$. Thirteen of the elective cases (52\%) were operated using open techniques, and 12 cases (48\%) were operated using laparoscopic techniques. In only one of the emergency cases, the operation was started laparoscopically, but due to insufficient exploration, the surgery was converted to an open technique (Table I).

In Group I, 16 patients (59.3\%) had a strangulated small intestinal segment in the hernia sac, and II (40.7\%) patients had a strangulated omentum majus in the hernia sac. In Group 2, I 4 (56\%) patients had no organs found in the hernia sac, and I I (44\%) patients had omentum in the hernia sac $(p<0.00$ I).

In Group I, in 12 patients (85\%), intestinal resection was not performed due to normalization of colour and circulation during perioperative wait and check, but four patients (15\%) underwent segmental small bowel resection and functional end-to-end anastomosis.

Fifteen (55\%) of the patients in Group I underwent a modified Lichtenstein technique, and 12 patients (45\%) underwent a Rutkow Plug. In two patients, small intestinal ischaemia was diagnosed, and midline laparotomy and segmental intestinal

Table I. Findings of the emergency surgery patients in Group I and elective surgery patients in Group 2

\begin{tabular}{lccc}
\hline & Group I $(\mathbf{n}=\mathbf{2 7})$ & Group 2 $(\mathbf{n}=\mathbf{2 5})$ & p \\
\hline Gender (male:female) & $23: 4$ & $23: 2$ & 0.667 \\
Mean age in years (range) & $68 \pm 15.8$ & $57.1 \pm 15.5$ & 0.013 \\
Laterality (left/right) & $8: 19$ & $11: 14$ & 0.282 \\
Average hospital stay (days) & $2.8 \pm 3.4$ & $1.08 \pm 0.26$ & $<0.001$ \\
Follow-up average duration & $16.6 \pm 16.3$ months & $11.76 \pm 13.73$ months & $=0.234$ \\
\hline
\end{tabular}


Table 2. Distribution of surgical techniques

\begin{tabular}{lccc}
\hline Group & $\begin{array}{c}\text { Modified } \\
\text { Lichtenstein } \\
(\mathbf{n}=19)\end{array}$ & $\begin{array}{c}\text { Rutkow } \\
(\mathbf{n}=19)\end{array}$ & $\begin{array}{c}\text { Laparoscopic } \\
\text { TAPP } \\
(\mathbf{n}=12)\end{array}$ \\
\hline Group 1 & 15 & 12 & 0 \\
Group 2 & 6 & 7 & 12 \\
\hline
\end{tabular}

TAPP: Transabdominal preperitoneal.

Table 3. Complications ethiology

\begin{tabular}{lcc}
\hline Complication ethiology & $\begin{array}{c}\text { Group I } \\
(\mathbf{n}=\mathbf{2 7})\end{array}$ & $\begin{array}{c}\text { Group 2 } \\
(\mathbf{n}=\mathbf{2 5})\end{array}$ \\
\hline Seroma & 4 & $\mathrm{I}$ \\
Wound infection & $\mathrm{I}$ & \\
lleus & $\mathrm{I}$ & \\
Anastomotic leakage & $\mathrm{I}$ & $\mathrm{I}$ \\
Pulmonary complications & & $2(8 \%)$ \\
Port side hernia & $7(26 \%)$ & \\
Total & & \\
\hline
\end{tabular}

resection with functional end-to-end anastomosis were performed. The other two segmental small bowel resections were performed at the groin incision after cutting the inguinal ligament. Of the patients in Group 2, six patients (24\%) underwent the Lichtenstein technique, seven patients (28\%) underwent a Rutkow Plug, and the remaining 12 patients (48\%) underwent the laparoscopic TAPP technique. The distribution of the surgical techniques according to the groups is summarized in Table 2.

Only one groin recurrence was detected $(2 \%)$. The patient who underwent emergency modified Lichtenstein repair was re-operated with laparoscopic TAPP I year later. In one case ( $2 \%)$, a port site hernia developed after the laparoscopic repair.

Postoperative complications were seen in 10 patients in this case series. Anastomotic leakage was detected after small bowel resection. The patient underwent re-operation, and a loop ileostomy was performed. One patient with aspiration pneumonia in Group I died on the $10^{\text {th }}$ day in the intensive care unit. Postoperative ileus occurred in one patient in Group I. There were no significant differences between the groups according to complications. Complications are summarized in Table 3.

The hospital stay was statistically longer for patients in Group I than in Group $2(p<0.001)$. The mean follow-up period was 16.6 16.3 months in emergency cases and $11.76 \pm 13.73$ months in the elective conditions $(p=0.234)$.

\section{DISCUSSION}

Groin hernias consist of inguinal and femoral hernias. The incidence of inguinal hernias in the United States is estimated to be between 5 and $10 \%$, with only $4 \%$ of these being femoral hernias. ${ }^{[14]}$ Although inguinal hernias are seen more frequently in all abdominal hernias (such as femoral, umbilical, and epigastric), femoral hernias also have a higher complication rate. ${ }^{[15]}$ In addition, approximately $40 \%$ of femoral hernia patients are admitted to emergency departments due to incarceration or strangulation. ${ }^{[6,17]}$ This study included patients who underwent emergency or elective surgery in two separate university hospitals. Over half of these patients were operated under emergency conditions, and the others were electively operated.

In previous studies, the incidence of femoral hernia in women and the need for emergency surgery were found to be significantly higher than in men. ${ }^{[1,5,18]}$ Therefore, it may be considered that elderly women have smaller inguinal and femoral channels than male patients. According to the Swedish hernia registry, the incidence of emergency hernia repair in female patients is $17 \%$ (53\% of femoral hernias), compared with $5 \%$ (7\% of femoral hernias) in male patients. In our study, the majority of women were operated on for femoral hernia according to emergency and elective operations, and there were no significant differences between the groups concerning the female/male ratio $(p=0.67)$. All patients in Group I referred to emergency services with an irreducible hernia, and all included small bowel or omentum majus.

In emergency femoral hernia operations, abdominal organ incarcerations are found higher in sac contents than in elective hernia operations. As a result, the rate of small bowel resection increases, the length of hospital stay is prolonged, and the mortality rate may increase up to 10 times. ${ }^{\left[{ }^{19]} \text { Early }\right.}$ diagnosis and appropriate surgical technique reduce the complication rate. ${ }^{[20]}$

In our study, in $59.3 \%$ of the patients in Group I, strangulated small bowel segments were found in the hernia sac. Only four patients (15\%) had a segmental intestinal resection. Suppiah et al. ${ }^{[21]}$ examined 75 femoral hernia surgeries and found the rate of a segmental intestinal resection anastomosis to be $57.1 \%(16 / 28)$ in patients who were operated on under emergency conditions. In a study conducted by Calik et al., ${ }^{[22]}$ organ resection was shown to be a factor increasing morbidity during femoral hernia surgery. In this study, anastomotic leakage occurred in only one patient, and a loop ileostomy was performed. The patient had a longer hospital stay because of this situation. One patient with femoral hernia had aspiration pneumonia because of vomiting as a result of incarceration. This patient died on the $10^{\text {th }}$ day in the intensive care unit.

Patients were operated on using three techniques: modified Lichtenstein, Rutkow plug and Laparoscopic TAPP. Repairs of 
femoral hernias with sutures bring about more recurrence than repairs with synthetic patches. ${ }^{[5,10]}$ In our series, all patients were treated with a synthetic patch repair. The Rutkow plug technique was completed for 19 patients, and this technique provides untensioned repair ${ }^{[23]}$ and is the main surgical technique in some series in the literature. ${ }^{[22,24]}$ Recurrence was detected in one patient (2\%) after the modified Lichtenstein technique. This patient was operated on under emergency conditions and then underwent repair with laparoscopic TAPP after one year. Twelve elective surgery patients (48\%) underwent laparoscopic TAPP. During emergency surgery, the laparoscopic technique was preferred in only one patient but underwent open surgery because of inadequate exploration, and a Rutkow plug was performed. In a patient who was operated on using the laparoscopic technique, a port site hernia developed at 8 months postoperatively and was repaired with a patch. No other early or late complications were encountered. The laparoscopic technique is similar to open techniques using patches, whereas it is superior to repair with only sutures. ${ }^{[15]}$ Although minimally invasive surgery is favourable, laparoscopy is not the preferred method in our clinics for cases of emergency surgery.

It has been reported that patients operated on in emergency conditions return for check-ups less frequently in the postoperative period than in elective conditions. ${ }^{[20]}$ In our study, the patients in both groups returned for their check-ups over an average of one year, and there were no significant differences between the groups.

The most important limitation of our study is that our study is a retrospective, non-randomized study. Despite being a multi-centre study, the number of patients seems inadequate. Thus, further research with a large number of patients can provide valuable insights.

\section{Conclusion}

Although incarceration and consequential intestinal ischaemia may be riskier and more complicated to operate on under emergency conditions, there were no significant differences in our study. ${ }^{[5,9]}$ It is suggested in the literature that early diagnosis of femoral hernias and elective surgery should be performed as soon as possible. ${ }^{[5,22]}$ As a result, femoral hernias should be diagnosed early, and incarceration should be performed early.

Although there were no significant differences between the groups in our study, the complication rate was more frequent and more serious in elderly patients in the emergency group. This study recommends that femoral hernias be diagnosed at an earlier age and operated under elective conditions. Thus, better surgical outcomes could be obtained.

A laparoscopic approach, such as TAPP, is recommended for femoral hernia operations for both emergency and elective procedures. Laparoscopy would apply control of ischaemia in strangulated bowel segments and enable hernia repair.

This study suggests early diagnosis and surgical intervention for femoral hernia and is similar to previous studies. The contribution of this study to the literature is the encouraging laparoscopic approach for both elective and emergency femoral hernia operations.

For the comparison of surgical techniques and outcomes, prospective randomized studies should be designed to standardize broad-based surgical techniques. It was difficult for us to obtain clear and healthy results because our work is retrospective and because of the small number of patients.

Conflict of interest: None declared.

\section{REFERENCES}

1. Ger R, Mishrick A, Hurwitz J, Romero C, Oddsen R. Management of groin hernias by laparoscopy. World J Surg 1993;17:46-50.[CrossRef]

2. Çetinkaya Z, Ayten R, Coşkun S. Kasık Fitıklarında Etyopatogenez ve Siniflandirma. J Surg Med Sci 2006;2:15-20.

3. Glassow F. Femoral hernia. Review of 2,105 repairs in a 17 year period. Am J Surg 1985;150:353-6. [CrossRef]

4. Bay-Nielsen M, Kehlet H, Strand L, Malmstrøm J, Andersen FH, Wara P, et al. Quality assessment of 26,304 herniorrhaphies in Denmark: a prospective nationwide study. Lancet 2001;358:1124-8. [CrossRef]

5. Dahlstrand U, Wollert S, Nordin P, Sandblom G, Gunnarsson U. Emergency femoral hernia repair: a study based on a national register. Ann Surg 2009;249:672-6. [CrossRef]

6. Kingsnorth A. Treating inguinal hernias. BMJ 2004;328:59-60 . [CrossRef]

7. Kulah B, Kulacoglu IH, Oruc MT, Duzgun AP, Moran M, Ozmen MM, et al. Presentation and outcome of incarcerated external hernias in adults. Am J Surg 2001;181:101-4. [CrossRef]

8. Kurt N, Oncel M, Ozkan Z, Bingul S. Risk and outcome of bowel resection in patients with incarcerated groin hernias: retrospective study. World J Surg 2003;27:741-3. [CrossRef]

9. Nilsson H, Stylianidis G, Haapamäki M, Nilsson E, Nordin P. Mortality after groin hernia surgery. Ann Surg 2007;245:656-60. [CrossRef]

10. Cakir M, Savas OA, Tuzun S, Tatar C. Preperitoneal Mesh Placement with Anterior Approach in Incarcerated Femoral Hernia (Our Experiences with 23 Cases). Haseki Tip Bülteni 2015;53:196-8. [CrossRef]

11. Sawayama H, Kanemitsu K, Okuma T, Inoue K, Yamamoto K, Baba H. Safety of polypropylene mesh for incarcerated groin and obturator hernias: a retrospective study of 110 patients. Hernia 2014;18:399-406.

12. Atila K, Guler S, Inal A, Sokmen S, Karademir S, Bora S.Prosthetic repair of acutely incarcerated groin hernias: a prospective clinical observational cohort study. Langenbecks Arch Surg 2010;395:563-8. [CrossRef]

13. Emir S, Sözen S, Yazar FM, Özkan Z, Çetinkünar S, Özdaş S. İnkarsere inguinal herni onarımında yama kullanımının güvenilirlik ve etkinliği: Bir klinik çalışma. Kafkas J Med Sci 2012;2:15-20. [CrossRef]

14. Rutkow IM, Robbins AW. Demographic, classificatory, and socioeconomic aspects of hernia repair in the United States. Surg Clin North Am 1993;73:413-26. [CrossRef]

15. Dabbas N, Adams K, Pearson K, Royle G. Frequency of abdominal wall hernias: is classical teaching out of date? JRSM Short Rep. 2011;2:5.

16. McIntosh A, Hutchinson A, Roberts A, Withers H. Evidence-based 
management of groin hernia in primary care--a systematic review. Fam Pract 2000;17:442-7. [CrossRef]

17. Ruhl CE, Everhart JE. Risk factors for inguinal hernia among adults in the US population. Am J Epidemiol 2007;165:1154-61. [CrossRef]

18. Rutkow IM. A selective history of groin hernia surgery in the early 19th century. The anatomic atlases of Astley Cooper, Franz Hesselbach, Antonio Scarpa, and Jules-Germain Cloquet. Surg Clin North Am 1998;78:921-40. [CrossRef]

19. Brittenden J, Heys SD, Eremin O. Femoral hernia: mortality and morbidity following elective and emergency surgery.J R Coll Surg Edinb 1991;36:86-8.

20. Dahlstrand U, Sandblom G, Wollert S, Gunnarsson U. Limited poten- tial for prevention of emergency surgery for femoral hernia. World J Surg 2014;38:1931-6. [CrossRef]

21. Suppiah A, Gatt M, Barandiaran J, Heng MS, Perry EP. Outcomes of emergency and elective femoral hernia surgery in four district general hospitals: a 4-year study. Hernia 2007;11:509-12. [CrossRef]

22. Calik B, Karaman K, Atci R, Cetindag O, Ugurlu L, Aydin C, et al. Visceral organ resection during femoral hernia surgery is a predictor of morbidity. Int Surg 2015;100:455-60. [CrossRef]

23. Swarnkar K, Hopper N, Nelson M, Feroz A, Stephenson BM. Sutureless mesh-plug femoral hernioplasty. Am J Surg 2003;186:201-2. [CrossRef]

24. Gallegos NC, Dawson J, Jarvis M, Hobsley M. Risk of strangulation in groin hernias. Br J Surg 1991;78:1171-3. [CrossRef]

\section{ORİJINAL ÇALIŞMA - ÖZET}

\section{Acil veya elektif uygulanmış femoral herni tamirinin cerrahi tekniği ve sonuçlarının karşılaştırılması \\ Dr. Enver Kunduz, ${ }^{1}$ Dr. İsmail Cem Sormaz, ${ }^{2}$ Dr. Yunus Yapalak, ${ }^{1}$ Dr. Hüseyin Kazım Bektaşoğlu, ${ }^{1}$ Dr. Ali Fuat Kaan Gök ${ }^{2}$}

${ }^{1}$ Bezmialem Üniversitesi Tıp Fakültesi, Genel Cerrahi Anabilim Dalı, İstanbul ${ }^{2}$ İstanbul Üniversitesi Tıp Fakültesi, Genel Cerrahi Anabilim Dalı, İstanbul

AMAÇ: Kasık fıtığı popülasyonun \%3-8'ini etkiler. Femoral herniler nadiren görülmekle birlikte genellikle acil cerrahi müdehale gerektirir ve sıklıkla bağırsak rezeksiyonu gerekebilmektedir. Bu çalışmanın amacı, acil veya efektif koşullar altında farklı teknikler kullanarak femoral herni olgularının cerrahi sonuçlarını karşılaştırmaktır.

GEREÇ VE YÖNTEM: Nisan 2013 ile Kasım 2017 arasında, İstanbul'daki iki üniversite hastanesinin genel cerrahi kliniklerinin acil servisine 52 femoral herni olgusu başvurdu. Femoral herni tanısı ile ameliyat edilen tüm hastaların tıbbi dosyaları geriye dönük olarak incelendi. Demografik veriler, taraf bilgisi, kesenin içeriği, cerrahi teknik, hastanede kalış süresi, son polikliniğe göre rekürrens ve komplikasyonlar geriye dönük olarak incelendi.

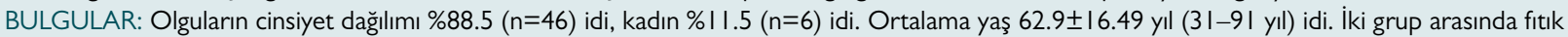
tarafına göre anlamlı fark yoktu ( $p=0.282$ ). Elektif olguların I3'ü (\%52) açık teknikle, I2'si (\%48) laparoskopik teknikle ameliyat edildi.

TARTIŞMA: Cerrahi tekniklerin ve sonuçların karşılaştırılması için, geniş tabanlı cerrahi teknikleri standart hale getirmek için ileriye yönelik randomize çalışmalar tasarlanmalıdır.

Anahtar sözcükler: Acil cerrahi; femoral herni; laparoskopi.

Ulus Travma Acil Cerrahi Derg 2019;25(6):6II-6I5 doi: 10.14744/tjtes.2019.04524 